\title{
Development of Augmented Reality for Children Book Lutung Kasarung
}

\author{
Frihandhika Permana $^{(1)}$, Rizdania Dermawi ${ }^{(2)}$, Sherina Izzaty $^{(3)}$ \\ ${ }^{(1)}$ Universitas Bina Nusantara, Indonesia \\ ${ }^{(2)}$ Universitas PGRI Wiranegara, Indonesia \\ ${ }^{(3)}$ Universitas Brawijaya, Indonesia
}

E-mail: (1)frihandhika.permana@binus.ac.id, ${ }^{(2)}$ rizdania@uniwara.ac.id, ${ }^{(3)}$ sherina.izzaty@gmail.com

Received: 4 November 2021; Revised: 25 November 2021; Accepted: 27 November 2021

\begin{abstract}
Folklore needs to be preserved and developed to improve the nation's emotional intelligence, especially the emotional intelligence of elementary school students who are the nation's next generation. With current technological advances, it is possible to develop an ordinary folklore book into a more interesting folklore book with the addition of Augmented Reality technology in it. By using the System Development Life Cycle (SDLC) method, an Augmented Reality-based application can be created to be able to make Lutung Kasarung children's folklore books can be enjoyed by getting experience that is more than just reading ordinary physical books because there is Augmented Reality technology inside. This Augmented Reality technology has 100\% accuracy if it meets the specified requirements, namely a distance of 45 centimeters and a height of 30 centimeters, and in testing at a distance of 50 centimeters, 55 centimeters, 60 centimeters, 65 centimeters with a height of 25 centimeters and 30 centimeters. In addition, with the AR Book, it is also expected to be able to introduce AR technology to both parents and children as an alternative to children's fairy tale books.
\end{abstract}

Keywords: Augmented Reality, Children's Storybook, Application.

\section{Introduction}

Folklore needs to be preserved and developed to improve the nation's emotional intelligence, especially the emotional intelligence of elementary school students who are the nation's next-generation (Kay, 2002). Therefore, there needs to be a development that is quite interesting so that folklore does not become boring.

Technology that has developed today is very fast and the longer the use of technology is easier to reach. Augmented Reality (AR) is a technology that is growing rapidly in various fields. AR Book or AR book is a small part of AR that offers a large number of opportunities for the development of new models of entertainment and education.

With current technological advances, it is possible to develop an ordinary folklore book into a more interesting folklore book with the addition of Augmented Reality technology in it. Which Augmented Reality technology will make story books that were previously only in the form of physical books into books that get interesting digital features, especially for children. Where children really like something new (Satya Yoga et al., 2015). For example, research by Hendra Adipta et al, entitled "Pemanfaatan Buku Cerita Bergambar Sebagai Sumber Bacaan Siswa Sd", shows that using picture fairy tale books is a great way to get students interested in learning. (Adipta et al., 2016)

Figure 1 is a display of Augmented Reality from Research on the Use of Augmented Reality as Learning Media for the Introduction of Fruits "by Anang Pramono and Martin Dwiky Setiawan in 2019. Afnida, et al 2016 (Tk \& Banda, 2016) with the title " Penggunaan Buku Cerita Bergambar DalamPengembangan Bahasa Anak Pada Tk a Di Banda Aceh ". This study aims to identify the use of illustrated fairy tales in children's language development in the city of Banda Aceh in Kindergarten A class. This research is descriptive 


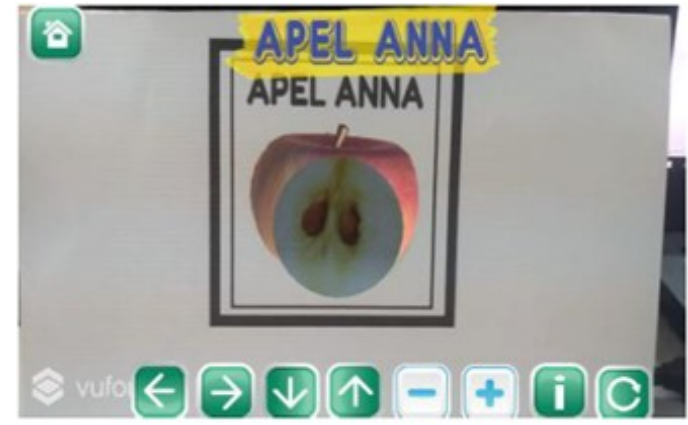

Figure 1. Augmented Reality

qualitative. The data was collected using observation and interview techniques. So this study concluded that the use of picture storybooks can greatly improve the language skills of children depending on the type of book given to children.

\section{Literature Review}

Augmented Reality (AR) is a system formed by mixing 2 virtual worlds and the real world. The merger will use computer graphics technology and applications that can change any atmosphere in the real world.

Augmented Reality (AR) is a technology that displays or provides virtual information to real objects. This can in principle be done using computer vision techniques. (Behzadan et al., 2015)

To show virtual objects in the real world using graphic computing technology. Graphical computing will process marker detection so that it can show the desired 3D object. In order to show the results of Augmented Reality, a monitor is needed to be able to display the results. (Kurniawan T. Martono, 2011)

Anang Pramono and Martin Dwiky Setiawan 2019 (Pramono \& Setiawan, 2019) with the title " Pemanfaatan Augmented Reality Sebagai Media Pembelajaran Pengenalan BuahBuahan ". They conducted research on Augmented Reality applications that display fruits using the MDLC (Multimedia Development Life Cycle) method.

\section{Material and Method}

The method used in making Augmented Reality in the Lutung Kasarung Folklore Book is the System Development Life Cycle (SDLC) (Kay, 2002).

The work structure used in this system will be described sequentially as follows:

a. Planning. At this stage, the author identifies what will be made starting from what is made, the programming language that will be used, the UI design that will be used, and what software and SDK will be used.

b. Analysis. The analysis phase is an investigation of the existing system to design a new system or update an existing system. What is being done at this time is to analyze various literature to understand how virtual objects can be displayed and can resemble physical objects using Augmented Reality technology.

c. Design. At this stage, the design process for the application and the book that is made is like what the shape of the image and also the interface of the software application looks like.

d. Application. In the implementation process where the process refers to the previous process, namely Design, this stage will use a program called Unity $3 \mathrm{D}$ and also use Vuforia to be able to process images and apply them using Augmented Reality technology. After the Augmented Reality application for the Lutung Kasarung Book is completed, the application will run on the Android operating system which has the following specifications according to the table.

e. Use. Users use the system to achieve the goals identified at the planning stage. The hardware used is a personal smartphone device with the type of smartphone, namely the Xiaomi Poco X3 Pro.

\section{Results and Discussion}

Using Augmented Reality Technology from Vuforia and made using Game Engine Unity 3D 2020 and Visual Studio Code using the C \# programming language. Physical books are used as media for real children and are also used as markers of the Augmented Reality application used. Figure 2 is a view of the front cover in Lutung Kasarung's physical book. Figure 3 is a display of one of the story pages from Lutung Kasarung's physical book. Figure 4, is a display of the narrative of one of the pages in Lutung Kasarung's physical book. Because the specialty of this fairy tale book lies in the presence of an Augmented Reality (AR) feature, all the illustrated images in it will become markers for AR objects.

Figure 5 is a display of how Augmented Reality works where the physical illustration image 
Table 1. Device Specification

\begin{tabular}{|l|l|}
\hline \multicolumn{1}{|c|}{ Component } & \multicolumn{1}{c|}{ Specification } \\
\hline Operating System & Android 11 (Marshmallow) \\
\hline CPU & Snapdragon 860 \\
\hline RAM & $8 \mathrm{~GB}$ \\
\hline GPU & Adreno 640 \\
\hline
\end{tabular}

that is only black and white will turn into color. And not only changing the color, when an object is detected and manages to issue a color image, but it will also be interspersed with a narration sound that matches the story in the image.

Figure 6 is a display of various pages that have used Augmented Reality technology. In its use, the Augmented Reality application cannot always capture the marker so that it displays the desired display, therefore distance testing is needed to determine how far the position of the smartphone that has been installed the Augmented Reality application Lutung Kasarung is to be able to capture the marker properly. The test results on the Augmented Reality Application on the distance parameter are as follows by Table 2

Figure 7 is a display of Augmented Reality test data in graphic form.

The experiment was carried out 3 times from a predetermined distance and height. The presentation calculation is the number of detected markers divided by the number of undetected markers and then multiplied by $100 \%$.

Table 2 and Figure 10 explain the results of testing the distance parameter in the Augmented Reality application Lutung Kasarung Storybook. The highest success rate is when the distance from the camera to the marker is 50 to 65 centimeters and with a height level of 20 centimeters to 30 centimeters, which results in a $100 \%$ success rate or it can be stated that with this high distance the market can be detected properly and the application can display colored objects and sounds as desired.

\section{Conclusion}

This AR Book Lutung Kasarung is expected to provide entertainment and lessons for children who read it. Some of the lessons that can be taken from this AR Book Lutung Kasarung include: having to love and care for each other between siblings and having to be proud to forgive each other.

In addition, with the AR Book, it is also

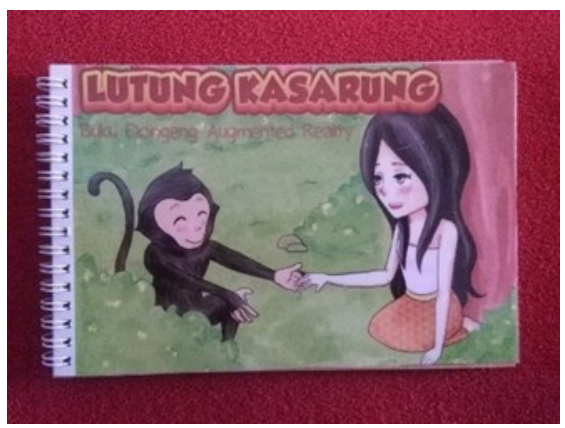

Figure 2. The Lutung Kasarung Storybook

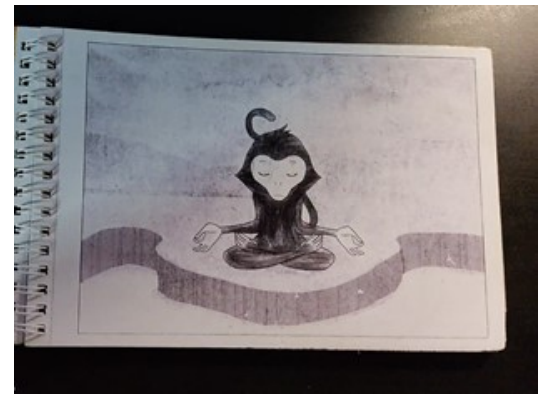

Figure 3. Book Drawing Pages

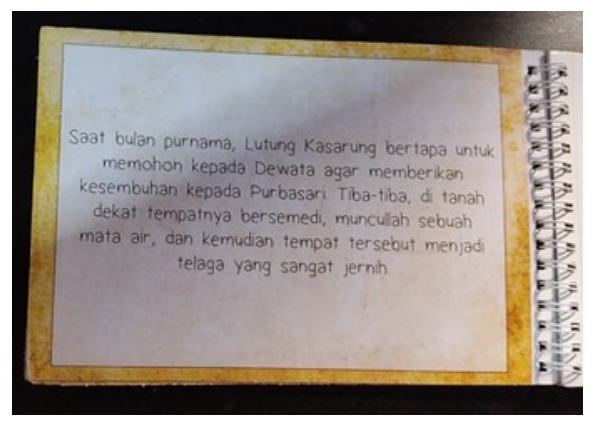

Figure 4. Book Narrative

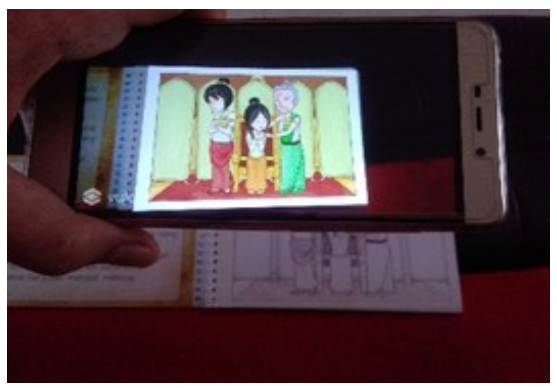

Figure 5. Display of Augmented Reality on Smartphone
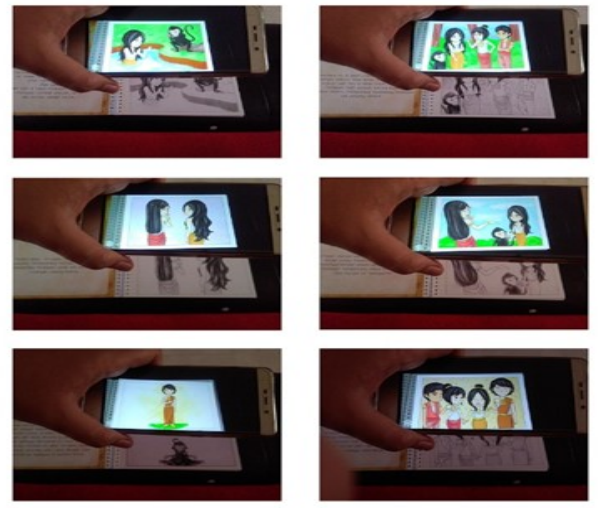

Figure 6. Collection of Augmented Reality Views 
Table 2. Augmented Reality Test Data

\begin{tabular}{|l|l|l|l|l|}
\hline & \multicolumn{5}{|c|}{ High (cm) } \\
\hline & 15 & 20 & 25 & 30 \\
\hline $\begin{array}{c}\text { Dstn } \\
(\mathrm{cm})\end{array}$ & $\begin{array}{c}\text { Avg } \\
\text { Success } \\
(\%)\end{array}$ & $\begin{array}{c}\text { Avg } \\
\text { Success } \\
(\%)\end{array}$ & $\begin{array}{c}\text { Avg } \\
\text { Success } \\
(\%)\end{array}$ & $\begin{array}{c}\text { Avg Suc- } \\
\text { cess (\%) }\end{array}$ \\
\hline 40 & 33,33 & 33,33 & 66,67 & 66,67 \\
\hline 45 & 33,33 & 33,33 & 66,67 & 100 \\
\hline 50 & 33,33 & 33,33 & 100 & 100 \\
\hline 55 & 33,33 & 33,33 & 100 & 100 \\
\hline 60 & 0 & 33,33 & 100 & 100 \\
\hline 65 & 0 & 86,66 & 100 & 100 \\
\hline 70 & 0 & 79,99 & 93,33 & 66,67 \\
\hline
\end{tabular}

Penghitungan Keberhasilan Augmented Reality

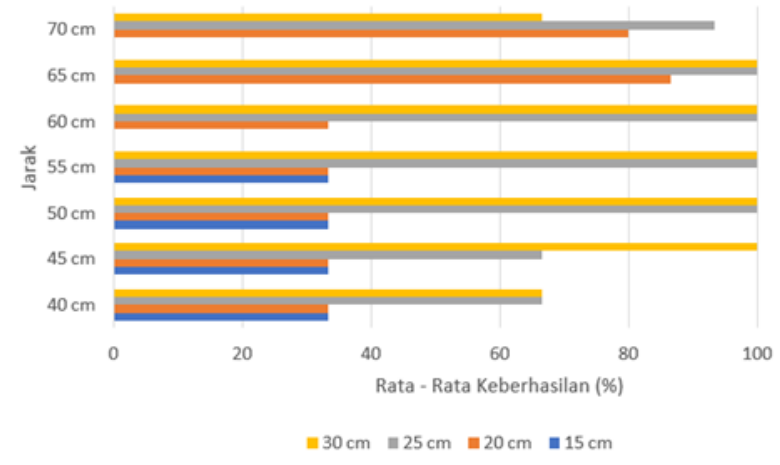

Figure 7. Graph of Augmented Reality Testing

expected to be able to introduce AR technology to both parents and children as an alternative to children's fairy tale books.

Because one of the natures of children is that they like to explore new things, in this AR Book Lutung Kasarung we add media for this, namely pictures that can be colored, where the pictures are marker images that have been removed from the greyscale color. -his.

For conditions of application use in order to run well is to meet the requirements for the placement of distance and height, namely a distance of 50 centimeters to 65 centimeters and a height of 20 centimeters to 30 centimeters. This requirement is used to maximize the detection process by smartphone devices so that they can detect markers properly and get $100 \%$ accuracy.Because one of the natures of children is that they like to explore new things, in this AR Book Lutung Kasarung we add media for this, namely pictures that can be colored, where the pictures are marker images that have been removed from the greyscale color. -his.
For conditions of application use in order to run well is to meet the requirements for the placement of distance and height, namely a distance of 50 centimeters to 65 centimeters and a height of 20 centimeters to 30 centimeters. This requirement is used to maximize the detection process by smartphone devices so that they can detect markers properly and get 100\% accuracy.

\section{References}

Adipta, H., Maryaeni, M., \& Hasanah, M. (2016). Pemanfaatan Buku Cerita Bergambar Sebagai Sumber Bacaan Siswa Sd. Jurnal Pendidikan: Teori, Penelitian, Dan Pengembangan, 1(5), 989-992. https:// doi.org/10.17977/jp.v1i5.6337

Behzadan, A. H., Dong, S., \& Kamat, V. R. (2015). Augmented Reality visualization: A review of civil infrastructure system applications. Advanced Engineering Informatics, 29(2), 252-267. https://doi.org/10.1016/ j.aei.2015.03.005

Kay, R. (2002). QuickStudy: System Development Life Cycle. Computerworld, 2002, 12 -13. http://www.computerworld.com/ printthis/2002/0,4814,71151,00.html\% 0Ahttp://scholar.google.com/scholar? $\mathrm{hl}=$ en\&btnG $=$ Search\&q=intitle:QuickStudy $+:+$ System + Development + Life + Cycle\#0

Kurniawan T. Martono. (2011). Augmented Reality sebagai Metafora Baru dalam Teknologi Interaksi Manusia dan Komputer. Jurnal Sistem Komputer, 1(2), 60-64. https:// doi.org/10.14710/JSK.V1I2.13

Pramono, A., \& Setiawan, M. D. (2019). Pemanfaatan Augmented Reality Sebagai Media Pembelajaran Pengenalan BuahBuahan. INTENSIF: Jurnal Ilmiah Penelitian Dan Penerapan Teknologi Sistem Informasi, 3(1), 54. https:// doi.org/10.29407/intensif.v3i1.12573

Satya Yoga, D., Suarmini, N. W., \& Prabowo, S. (2015). Peran Keluarga Sangat Penting dalam Pendidikan Mental, Karakter Anak serta Budi Pekerti Anak. Jurnal Sosial Humaniora, 8(1), 46. https://doi.org/10.12962/ j24433527.v8i1.1241

Tk, P., \& Banda, A. D. I. (2016). Penggunaan Buku Cerita Bergambar DalamPengembangan Bahasa Anak Pada Tk a Di Banda Aceh. 1(1), 53-59. 